\title{
DISABILITY, DEGRADATION AND DIGNITY: THE ROLE OF ARTICLE 3 OF THE EUROPEAN CONVENTION ON HUMAN RIGHTS
}

\author{
Anna Lawson, School of Law and Centre for Disability Studies, \\ University of Leeds*
}

\section{Introduction}

Traditionally, disability has not been regarded as a human rights issue. It has instead been viewed as a medical problem calling for medical solutions and for the support, through welfare or charity, of those who cannot be cured or corrected. The disability movement has insisted that disability is a human rights issue and that the attention of legislators and policy makers should be focussed on the physical, social, attitudinal, legal and other barriers which prevent disabled people participating in mainstream society. ${ }^{1}$ In the language of the social model of disability, ${ }^{2}$ it is societal barriers such as these which disable people who have physical, sensory, intellectual or other impairments.

The disability movement, then, calls for the dismantling of disabling societal obstacles and for the development of laws and policies which foster principles of inclusion and participation. Its goal is a society in which people with impairments are neither deliberately nor unthinkingly disabled by the

\footnotetext{
* This article originated in a paper ("Article 3 and Disabled People: Humanity, Degradation and Dignity") delivered at a conference ("Human Rights \& Disability Discrimination: Exploring the value added by the ECHR and other sources of European Law") held in the University of Galway on 25 September 2004 the proceedings of which are due to be published jointly by the Disability Law \& Policy Research Unit, Faculty of Law, NUI Galway and the Irish Equality Authority. I would like to record my thanks to Donncha O'Connell and the other organisers of that Conference, as well as to all its participants, for the opportunity to discuss some of the ideas considered here. I would also like to thank Caroline Gooding (Disability Rights Commission), Steven Wheatley (University of Leeds) and Colin Harvey (Queens University Belfast) for their very helpful comments on earlier drafts.

1 See further, C. Barnes, Disabled People in Britain and Discrimination: a Case for Anti-Discrimination Legislation (London: Hurst/BCODP, 1991) ; C. Barnes and G. Mercer, Disability (Oxford: Polity Press, 2003); C. Barnes (ed.), Implementing the Social Model of Disability: Theory and Research (Leeds: The Disability Press, 2004); T. Degener, "Disabled Persons and Human Rights: The Legal Framework" in T. Degener and Y. Koster-Dreese (eds), Human Rights and Disabled Persons: Essays and Relevant Human Rights Instruments (Dordrécht/Boston/London: Martinus Nijhoff, 1995); J. Campbell and M. Oliver, Disability Politics: Understanding our Past, Changing our Future (New York: Routledge, 1996); M. Oliver, The Politics of Disablement (Basingstoke: Macmillan, 1990); M. Oliver, Understanding Disability: From Theory to Practice, (Basingstoke: Macmillan, 1996); M. Priestley, "Constructions and Creations: Idealism, Materialism and Disability Theory" (1998) 13 Disability \& Society 75.

2 See, e.g. Union of Physically Impaired Against Segregation, Fundamental Principles of Disability (London: UPIAS/Disability Alliance, 1976).
} 
world around them: a society in which their individuality is valued and in which their dignity is respected. Human rights law has an essential role to play in the creation of such a society.

Although the protection of human dignity is a concern which runs throughout the European Convention on Human Rights 1950 (ECHR), it finds its clearest expression in Article 3, according to which:

"No one shall be subjected to torture or to inhuman or degrading treatment or punishment."

Potentially, then, Article 3 has a particularly important role to play in ensuring that people with impairments are treated as valued and respected members of society. It is my aim here to explore the scope of this potential role and the extent to which it has been developed to date.

While this discussion will be of relevance to disabled people in all countries in which the ECHR has effect, its prime focus will be the UK. The advent of the Human Rights Act 1998 has already generated a substantial body of UK Article 3 cases to add to those of the European Court of Human Rights (ECtHR). ${ }^{4}$ Although many of these UK cases have arisen in contexts far removed from disability, the principles developed in them have obvious relevance to disabled people.

It should be stressed that no precise definition underlies references to the term "disabled" in this article. One of the great strengths of the ECHR is that, unlike statutes such as the Disability Discrimination Act $1995,{ }^{5}$ its protection is not conditional on compliance with any rigid definition of disability. The term will be used here simply to refer to people who have physical, mental, intellectual or sensory impairments (including those caused by serious illness).

In the next section I will provide a brief outline of the general scope of Article 3 and will attempt to draw out some of its aspects which have particular relevance for disabled people (despite the fact that these aspects have, to date, been developed largely in non-disability contexts). In the following section I will examine the way in which Article 3 has been used in cases (both of UK courts and of the ECtHR) concerning disabled people. That section will be divided into three parts reflecting three different types of living environment in which disabled people have found themselves and

3 Article 5 of the Universal Declaration of Human Rights 1948 is couched in very similar terms. Other relevant UN provisions are Articles 7 and 10 of the International Covenant on Civil and Political Rights 1966 and also the Convention against Torture and Other Cruel, Inhuman or Degrading Treatment or Punishment 1984. See generally, G. Quinn, "The Integrity of the Person: The Convention Against Torture and Other Cruel, Inhuman or Degrading Treatment or Punishment and Disability" in G. Quinn and T. Degener (eds), Human Rights and Disability the current use and future potential of United Nations Human rights instruments in the context of disability (UN, November 2002), at www.ohchr.org/english/issues /disability/study.htm (last visited 3 August 2005).

4 For an analysis of the impact of these cases on various sectors of the population, see, C. Harvey (ed.), Human Rights in the Community (Oxford: Hart Publishing, 2005).

5 Section 1 of which defines a "disabled person". See further, G. James, "The Meaning of Disability: Physical and Mental Impairment" [2002] ILJ 156. 
which generate slightly different considerations for Article 3: first, prisons; second, other institutions and, finally, the home environment. The prison environment is addressed first because it is in that context that the Article 3 jurisprudence relating to disability has been most fully developed. I will argue that, although the cases demonstrate that Article 3 has begun to play a role in the promotion and protection of the dignity, safety and self-respect of disabled people in this country, its potential is currently under exploited, particularly in situations where the suffering is experienced by people living in their own homes. In the final substantive section I will consider the debate surrounding the issue of whether Article 3 does in fact offer protection to all or whether there are some disabled people who fall completely outside its reach.

\section{Scope of Article 3}

\section{“Torture", "Inhuman" and "Degrading"}

The terms "torture", "inhuman", and "degrading" in Article 3 have not been precisely defined. Some general guidance, however, can be gleaned from cases such as Ireland v $U K^{6}$

"Torture" generally requires deliberate inhuman treatment, causing very serious and cruel suffering, which is inflicted for one of a number of purposes (including the extraction of information or confessions). ${ }^{7}$ "Inhuman" treatment or punishment generally involves intense physical or mental suffering. 8 "Degrading" treatment or punishment, on the other hand, focuses on the notion of humiliation; being treatment which arouses in the victim "feelings of fear, anguish and inferiority" capable of humiliating and debasing them and of "breaking their physical and moral resistance". 9 For "inhuman" or "degrading" treatment, a deliberate intention to cause suffering or to humiliate and debase is an important, but not an essential, factor. ${ }^{10}$ In cases where there is no such intent, particular attention will be paid to the State's response to the situation and its attempts to alleviate the relevant suffering.

Disabled people are, by no means, strangers to the deliberate infliction of cruelty or exploitation. This is recognized by Rule 9(4) of the UN Standard

6 Series A no 25 (18 Jan 1978); see also The Greek Case (1969) 12 YB 1501.

7 See Aydin v Turkey (1997) 25 EHRR 251. See generally J. Cooper, Cruelty: An Analysis of Article 3 (London: Sweet and Maxwell, 2003), 9-17; D. Feldman, Civil Liberties and Human Rights in England and Wales (Oxford: Oxford University Press, 2002), 245-246; and P.J. Duffy, "Article 3 of the European Convention on Human Rights" (1983) 32 ICLQ 316, 316-318.

8 See generally J. Cooper, Cruelty: An Analysis of Article 3 (ibid.) 21-22; and PJ. Duffy, "Article 3 of the European Convention on Human Rights" (ibid.), 318.

9 Pretty v UK (2002) 35 EHRR 1, para.52. See generally J. Cooper, Cruelty: An Analysis of Article 3 (ibid.), 22-23; P.J. Duffy, "Article 3 of the European Convention on Human Rights" (ibid.), 319-320; J. Vorhaus, "On Degradation: Degrading Treatment And Punishment" [2003] CLWR 65; and R.A. Duff, "Punishment, Dignity and Degradation" (2005) 25 OJLS 141, especially at 149155.

10 V v UK [2000] 30 EHRR 121, para.71; Peers v Greece [2001] 33 EHRR 51, para.74. 
Rules on the Equalisation of Opportunities for Disabled People 1993 which draws attention to the fact that they are "particularly vulnerable to abuse". ${ }^{11}$ Nevertheless, it seems probable that the suffering and humiliation which disabled people experience is more often the result of neglect or of failure to make adjustments in their favour or to provide them with necessary support. The Article 3 concepts of "inhuman" and "degrading" treatment are therefore likely to be of more assistance to them than is that of "torture".

Article 3's prohibition of torture and inhuman or degrading treatment or punishment is absolute, allowing no exceptions or limitations. The courts have consequently set a high threshold for entry into its realms. Suffering must reach a certain minimum level before it can amount to an Article 3 violation. ${ }^{12}$

As well as imposing a negative obligation on States to refrain from inflicting torture or inhuman or degrading treatment or punishment on its citizens, Article 3 has been held to require that they conduct appropriate investigations into possible breaches of Article 3 which come to their attention. ${ }^{13}$ It also imposes positive obligations which require States to take reasonable steps to protect those at a real risk of experiencing relevant suffering. These positive obligations widen the scope of Article 3 and considerably increase its potential usefulness to disabled people. They will therefore be considered in more depth below. First, however, some attention will be given to the concept of "treatment" used in Article 3.

\section{"Treatment"}

It should be stressed at the outset that, although many impairments may bring with them intense pain and suffering, Article 3's negative prohibition against inflicting inhuman or degrading treatment will not be violated unless it can be shown that that suffering has, or may have been, exacerbated by treatment for which the authorities can be held responsible. ${ }^{14}$ Identification of such treatment is far from unproblematic. In Pretty v $U K,{ }^{15}$ Diane Pretty argued that her husband should be able to assist her to commit suicide, without fear of criminal prosecution, in order to spare her from the humiliation and degradation which she would otherwise suffer in the last stages of her terminal illness. She contended that the State's refusal to refrain from prosecuting her husband, should he assist her, amounted to treatment which exacerbated her suffering and which therefore violated Article 3. This argument was rejected. ${ }^{16}$ The suffering in question was caused entirely by her medical condition and the refusal of the State to exempt her husband from

11 See further, H. Brown, Safeguarding Adults and Children with Disabilities Against Abuse (Strasbourg: Council of Europe Publishing, 2002).

12 See, e.g. Pretty v UK (2002) 35 EHRR 1, para.52. See generally J. Cooper, Cruelty: An Analysis of Article 3 ( 7 above).

13 Assenov v Bulgaria (1998) 28 EHRR 652; see also A. Mowbray, "Duties of Investigation Under the European Convention on Human Rights" (2002) 51 ICLQ 435.

14 Pretty v UK (2002) 35 EHRR 1, para.52. See also A. Petain, "The Human Rights Dimensions of the Diane Pretty Case" [2003] CLJ 181.

15 ibid.

16 ibid., at para.53. 
criminal prosecution did not constitute "treatment" within the meaning of Article 3.

The ECtHR in Pretty distinguished the case before it from that of $D \vee U K .^{17}$ There, the ECtHR had held that the UK would violate Article 3 if it implemented its decision to deport a prisoner dying of AIDS to St Kitts. This was because, if returned to St Kitts, there would have been no prospect of him receiving medical treatment or family support and there would consequently have been a real risk that he would die in extremely painful and distressing circumstances. "Treatment", in $D$, could be located in the expulsion of the claimant from the country which would have exacerbated the suffering flowing from his naturally occurring illness.

In Pretty there is some reference to the fact that, in $D$, the expulsion would have constituted an "act" in contrast to the situation in Pretty itself where there was no such "act". ${ }^{18}$ Nowhere, however, does the ECtHR stipulate that "treatment" must always take the form of an act rather than an omission.

In the UK, the statutory regime imposed on asylum seekers (which prevents them both from working ${ }^{19}$ and from receiving State support ${ }^{20}$ ) has recently been held to constitute "treatment" within the meaning of Article $3 .^{21}$ According to Phillips MR in $R \mathrm{v}$ Sec of State for the Home Dept, ex $p Q$ :

"Treatment, ... implies something more than passivity on the part of the State; but here, it seems to us, there is more than passivity. ... The imposition by the legislature of a regime which prohibits asylum seekers from working and further prohibits the grant to them, when they are destitute, of support amounts to positive action directed against asylum seekers and not to mere inaction." 22

Lord Scott, in $R$ v Sec of State for the Home Dept, ex p Adam, Limbuela and Tesema, ${ }^{23}$ was at pains to stress that there would not be any relevant "treatment" where destitution or homelessness could be attributed only to a failure of a State to adopt effective preventative measures. It was not the function of Article 3, in his view, "to prescribe a minimum standard of social support for those in need" 24 and consequently "treatment" required "something more than mere failure". 25

17 (1997) 24 EHRR 423.

18 (2002) 35 EHRR 1, para.53.

19 Asylum and Immigration Act 1996, s.8.

20 The Immigration Nationality and Asylum Act 2002, s.51(1).

${ }^{21} R \mathrm{v}$ Sec of State for the Home Dept, exp $Q$ [2004] QB 36 and $R$ v Sec of State for the Home Dept, ex p Adam, Limbuela and Tesema [2005] UKHL 66. For criticism of this aspect of the decision in $Q$, see Sec of State for the Home Dept $\mathrm{v}$ Limbuela and Others [2004] QB 1440, paras.[115]-[117] per Carnwarth LJ.

22 [2004] QB 36, para.[56]; approved in $R$ v Sec of State for the Home Dept, ex $p$ Adam, Limbuela and Tesema [2005] UKHL 66, at para.[6] per Lord Bingham and para.[56] per Lord Hope.

23 ibid.

24 ibid., at para.[66]. See also para.[7] per Lord Bingham.

25 ibid. 
It is unclear how this emerging test for "treatment" would operate in cases where suffering is exacerbated, not by a legislative scheme as such, but by a negligent failure to apply it. If, for instance, a disabled person's suffering were exacerbated by the failure of their Local Authority to take any steps to provide them with support to which they were entitled, should the Authority's failure to act (in breach of a statutory duty) be characterised as passivity or, alternatively, as some form of positive failing and therefore as relevant "treatment"? As will be demonstrated below, there is clear authority to the effect that Article 3 may be engaged where suffering has been caused or exacerbated by similar types of State omission or failure to act. ${ }^{26}$ If the meaning of "treatment" is to be confined to positive acts, it is therefore important that "treatment" is not viewed as an essential pre-requisite of every Article 3 violation not involving torture or punishment. It may be argued, for instance, that it should not be required in cases where Article 3 is found to impose a positive obligation on States to take steps to prevent relevant suffering. ${ }^{27}$

In any event, when faced with decisions as to whether or not there was any relevant "treatment" in a particular case, it is clear that judges should bear in mind the ECtHR's observation in Pretty that the interpretation given to such terms must accord with the "fundamental objectives of the Convention and its coherence as a system of human rights protection". ${ }^{28}$ Consideration should therefore always be given to the consequences of a decision as to the existence of "treatment". This, it is hoped, will reduce the risk of an overly rigid distinction between action and passivity becoming determinative of liability for human rights abuses..$^{29}$

\section{Negative and Positive Obligations}

Reference has already been made to the existence of both negative obligations to refrain from inflicting inhuman and degrading treatment and positive obligations to take measures to prevent Article 3 suffering occurring. In a commonly cited passage, the ECtHR in Pretty outlined this distinction as follows:

"50. An examination of the Court's case-law indicates that Article 3 has been most commonly applied in contexts in which the risk to the individual of being subjected to any of the proscribed forms of treatment emanated from intentionally inflicted acts of State agents or public authorities . . . . It may be described in general terms as imposing a primarily negative obligation on States to refrain from inflicting serious harm on persons within their jurisdiction. However, in light of the fundamental importance of Article 3, the Court has reserved to itself sufficient flexibility to address the application of that Article in other situations that might arise ...

26 See the text accompanying nn.36 and 37 below.

27 This appears to have been assumed to be the case in $R \mathrm{v}$ Sec of State for the Home Dept, ex $Q$ [2004] QB 36 at paras.[51]-[52].

28 (2002) 35 EHRR 1, para.54.

29 In $R$ v Sec of State for the Home Dept, ex p Adam, Limbuela and Tesema [2005] UKHL 66 at para.[92] Lord Brown described this distinction as a "false dichotom[y]" reliance on which was "unhelpful". 
51. In particular, the Court has held that the obligation on the High Contracting Parties under Article 1 of the Convention to secure to everyone within their jurisdiction the rights and freedoms defined in the Convention, taken in conjunction with Article 3, requires States to take measures designed to ensure that individuals within their jurisdiction are not subjected to torture or inhuman and degrading treatment or punishment, including such treatment administered by private individuals ....". ${ }^{30}$

Clear disability-related examples of treatment which might violate the negative prohibition of Article 3 may be envisaged. They would include the State authorisation of programmes under which people with mental impairments, who lack the ability to withhold consent, are subjected to medical experimentation; and the application to such people of unnecessarily harsh and invasive forms of restraint in institutional settings. Given the nature of the judicial guidance to date, however, any identification of disability-related examples of Article 3's positive obligations must necessarily be more tentative. ${ }^{31}$

The ECtHR has declined to provide any definitive guidance as to the scope of positive obligations or as to their relationship with their more familiar negative counterparts. ${ }^{32}$ Carnwarth LJ has summarised the effect of the relevant ECtHR and UK case law as follows:

"The general proposition which emerges is unremarkable. It is that, in areas of state responsibility, where state action or inaction may lead to suffering sufficiently serious to engage Article 3, the relevant state agency has a duty to take reasonable steps to avoid it." 33

In Pretty v $U K^{34}$ it was suggested that positive obligations invoked under Article 3 should "involve the removal or mitigation of harm by, for instance, preventing any ill-treatment by public bodies or private individuals or providing improved conditions or care". Thus, in $A \mathrm{v} U K^{35}$ a positive obligation was invoked to prevent ill-treatment at the hands of a private individual. The same objective underlies the obligation invoked in $Z \mathrm{v} U K{ }^{36}$ though the provision of improved conditions or care was also relevant in that case.

$Z$, it is suggested, has particular significance for disabled people wishing to invoke a positive obligation requiring State authorities to implement existing policies effectively in order to ensure that their suffering does not cross the

30 (2002) 35 EHRR 1.

31 See generally, K. Starmer "Positive Obligations Under the Convention" in J. Jowell and J. Cooper (eds), Understanding Human Rights Principles (Oxford: Hart Publishing, 2001); and A. Mowbray, The Development of Positive Obligations Under the European Convention on Human Rights by the European Court of Human Rights (Oxford: Hart Publishing, 2004).

32 Platform Artze fur das Leben v Austria (1991) 13 EHRR 204.

33 Gezer v Sec of State for the Home Dept [2004] EWCA (Civ) 1730, para.[46].

34 (2002) 35 EHRR 1, para.55.

35 100/1997/884/1096 (23 September 1998).

36 (2002) 34 EHRR 97. 
Article 3 threshold. A Local Authority was there held to have violated Article 3 through its neglect or failure to act. The Council, which had been under a statutory duty to protect the four children concerned, had allowed them to remain in their home for four and a half years after discovering that they were at risk of serious neglect and also physical abuse. Thus, the Authority had violated Article 3, not by any deliberate act, but by a "failure of the system". 37

The ECtHR has indicated that, while the negative prohibition of Article 3 is absolute and unqualified, its positive obligations are not. ${ }^{38}$ The positive duty is to take only such steps as are reasonable to prevent ill treatment of which the authorities know or ought to have known. In the context of the analogous duty under Article 2, the ECtHR has explained that "such an obligation must be interpreted in a way which does not impose an impossible or disproportionate burden on the authorities" and that whether it is violated "is a question which can only be answered in the light of all the circumstances of any particular case". ${ }^{39}$ In the words of Lord Bingham, approved by the ECtHR in Pretty:

"It stands to reason that while States may be absolutely forbidden to inflict the prescribed treatment on individuals within their jurisdictions, the steps appropriate or necessary to discharge a positive obligation will be more judgmental, more prone to variation from State to State, more dependent on the opinions and beliefs of the people and less susceptible to any universal injunction." 40

Unlike the negative obligation, therefore, a positive obligation would allow States an opportunity to advance a justification for their part in bringing about the suffering in question. This contrast between the absolute nature of the negative prohibition and the more qualified nature of the positive obligation creates an inevitable temptation to set up a clear bright-line dichotomy between them. In recent asylum seeker cases, however, the Court of Appeal has doubted the practical benefit of any such distinction to judges faced with decisions as to whether or not there has been an Article 3 violation in a particular case. While recognising that the categorisation of obligations as positive or negative constitutes "a valuable tool for analyzing the jurisprudence in this area", ${ }^{41}$ it has described the distance between them as "in practice fairly narrow"; 42 and the distinction as of limited utility, ${ }^{43}$ as likely to give rise to "sterile arguments", ${ }^{44}$ and as "not establish[ing] the

37 ibid., at para.74.

38 See Pretty v $U K$ (2002) 35 EHRR 1, para.14, quoting from $R$ v DPP, ex p Pretty [2002] 1 AC 800, para.[15] per Lord Bingham.

39 Osman v UK 87/1997/871/1083 28 October 1998 at para.116.

$40 R$ v DPP, ex p Pretty [2002] 1 AC 800, para.[15].

41 Gezer v Sec of State for the Home Dept [2004] EWCA (Civ) 1730, para.[56] per Elias J.

$42 R$ v Sec of State for the Home Dept, ex p $Q$ [2004] QB 36, para.[52] per Phillips MR.

43 Gezer v Sec of State for the Home Dept [2004] EWCA (Civ) 1730, para.[28] per Laws LJ.

44 ibid. 
touchstone by which the nature of the State's obligation can be defined" ${ }^{45}$ These concerns have been echoed in the House of Lords, particularly by Lord Brown ${ }^{46}$ Indeed, the difficulty is well illustrated by the fact that, while Phillips $\mathrm{MR}^{47}$ and Laws $\mathrm{LJ}^{48}$ have confidently characterised the obligation at issue in $D$ as a negative one (to refrain from inflicting inhuman and degrading treatment through deportation), Lord Brown ${ }^{49}$ has insisted that it is "essential" that such an obligation should be acknowledged to be a positive one (to continue the provision of medical treatment in the UK to the wouldbe immigrant).

Attempts have been made to articulate the distinction between cases in which justifications may and may not be advanced in terms other than those of positive and negative obligations. In $R \mathrm{v}$ Sec of State for the Home Dept, ex $p$ Adam, Limbuela and Tesema,$^{50}$ for instance, Lord Hope suggested that the key distinction was between cases in which the State was directly responsible for the relevant suffering and ones in which it was only indirectly responsible. ${ }^{51}$ Similarly, Baroness Hale suggested that it was between cases in which the suffering had been inflicted by the State itself and ones in which the State should have intervened in order to protect a person from suffering inflicted by others. ${ }^{52}$ Laws LJ has offered an alternative categorisation based on the distinction between cases of deliberate State violence and others in which State acts or omissions have exposed a person to relevant suffering. Despite the centrality of this distinction to Laws LJ's analysis, he has depicted the range of Article 3 obligations as a spectrum.

\section{Lord Justice Laws’ Article 3 spectrum}

In Sec of State for the Home Dept v Limbuela and others ${ }^{53}$ and Gezer v Sec of State for the Home Dept ${ }^{54}$ Laws LJ set out his spectrum analysis of Article 3 obligations. At its heart, as mentioned above, lies a distinction between two types of case which, according to his Lordship is, "well recognised in the jurisprudence, but whose importance has perhaps not always been fully unraveled". 55 In category (a) lies the deliberate use of unlawful violence by State officials. ${ }^{56}$ Category (b), on the other hand,

45 ibid., at para.[56] per Elias J.

46 In $N(F C)$ v Sec of State for the Home Dept [2005] 2 AC 296, para.[88] and $R$ v Sec of State for the Home Dept, ex p Adam, Limbuela and Tesema [2005] UKHL 66, paras.[91]-[95].

$47 R \mathrm{v}$ Sec of State for the Home Dept, ex $p Q$ [2004] QB 36, para.[54].

48 Sec of State for the Home Dept v Limbuela and Others [2004] QB 1440, para.[64].

$49 N(F C)$ v Sec of State for the Home Dept [2005] 2 AC 296, para.[88].

50 [2005] UKHL 66.

51 ibid., paras.[48] and [55].

52 ibid., para.[77].

53 [2004] QB 1440, paras.[69]-[70].

54 [2004] EWCA (Civ) 1730.

55 Sec of State for the Home Dept v Limbuela and others [2004] QB 1440, para.[59].

56 In Gezer v Sec of State for the Home Dept [2004] EWCA (Civ) 1730, para.[24], he added ambiguously that this category might also include "other grave illtreatment". However, there is no elaboration of this and the judgements do contain a clear emphasis on the significance of violence. 
consists of "acts or omissions by the State which expose the claimant to suffering inflicted by third parties or by circumstance". ${ }^{57}$

Both categories contain subdivisions. Category (a) contains, first, authorised State violence and, second, unauthorised violence by State officials. Such unauthorised violence may take the form either of the use of excessive force in the discharge of authorised State business or of violence which has "no colour" of authority at all..$^{58}$ Category (b) breaks down into cases in which the suffering is the result of violence inflicted by non-State officials, on the one hand and where it is the result of circumstances resulting from State acts or omissions, on the other. These different scenarios, according to Laws LJ, represent different points on a spectrum.

The paradigm case of Article 3 violation is that of State authorised violence which, subject to a limited number of very clearly defined exceptions (relating, for instance, to the use of reasonable force in the execution of arrests) is totally prohibited by the Article and cannot be justified. In these cases Article 3's prohibition constitutes "the law's first and only word". 59 At the other end of the spectrum lie cases such as $D \vee U K^{60}$ in which the suffering has been caused, not by violence, but by circumstances created by acts or omissions of the State in pursuance of lawful policy. Article 3 may, on occasion, be violated in these cases but only if the suffering is exceptional and if allowing the claim would hold a fair balance between the interests of the particular claimant and those of the general public. ${ }^{61}$ In such cases, Article 3 is "no more nor less than the law's last word", operating as "a safety net, confining the State's freedom of action only in exceptional or extreme cases". ${ }^{62}$ Between these two ends of the spectrum, in relation to the State's obligation to prevent, investigate and punish unauthorised violence for instance, the law allows States "a measure of judgment in the elaboration of measures to serve the aims". ${ }^{63}$ This measure of judgment, however, would be much narrower than it would be in cases at the $D \mathrm{v} U K$ end of the spectrum.

According to Laws LJ, although there will be some point which divides State acts or omissions violating Article 3 from those which do not, there is no "brightline rule" for determining exactly where this point lies. ${ }^{64}$ In his words:

57 Sec of State for the Home Dept v Limbuela and others [2004] QB 1440, para.[59].

58 ibid., at para.[65].

59 ibid., at para.[77].

60 (1997) 24 EHRR 423.

61 Thus, according to the House of Lords in $N$ v Sec of State for the Home Dept [2005] 2 AC 296, $D$ has been narrowly confined by subsequent ECtHR cases to situations in which the person who would otherwise be deported is actually dying and the potential receiving country offers no relevant medical treatment at all. Expansion beyond these narrow confines would impose too heavy a burden on citizens of the expelling country, the immigration policies of which might be seriously undermined. For discussion of the Court of Appeal's decision in $N$, see C. Sawyer, "Insufficiently Inhuman: Removing AIDS Patients from the UK" [2004] JSWFL 281.

62 Sec of State for the Home Dept v Limbuela and Others [2004] QB 1440, para.[77].

63 ibid.

64 ibid., at para.[71]. 
"The point is at the place between cases where government action is justified notwithstanding the individual's suffering, and cases where it is not. Various factors will determine where this place is to be found. They will include the severity of the threatened suffering, its origin in violence or otherwise, and the nature of the government's reasons or purpose in acting as it does." 65

Laws LJ stressed that the division between categories (a) and (b) should not be equated with the distinction between negative and positive obligations. ${ }^{66}$ Many scenarios, in his view, would give rise to both negative and positive obligations.

"The State's duty to protect individuals from Article 3 illtreatment will, depending on the circumstances, sometimes involve refraining from action, and sometimes involve taking action. In the context of the duty to protect the difference is serendipitous. But in category (a) cases - and especially their most heinous instance, State-sponsored violence - it is misleading to speak merely of a duty to protect: such things are, simply, absolutely forbidden." ${ }^{\circ 7}$

The current status of Laws LJ's spectrum analysis is somewhat uncertain. It was approved by the other members of the Court of Appeal in both Limbuela and Gezer and by the House of Lords in $N .^{68}$ In the more recent case of $R \mathrm{v}$ Sec of State for the Home Dept, ex $p$ Adam, Limbuela and Tesema, ${ }^{69}$ however, Lord Hope and Baroness Hale expressed disquiet about it and concern that it lacked a solid grounding in the jurisprudence of the ECtHR. ${ }^{70}$ They stressed that issues of proportionality or justification had no role at all to play in cases where the State was directly responsible for the relevant suffering, even if that was as a result of what Laws LJ had termed "legitimate government policy" not involving violence. ${ }^{71}$ Lord Brown, on the other hand, expressed broad agreement with Laws LJ's approach because it highlighted "the many different considerations in play and the need in all but the clearest cases "to look at the problem in the round". ${ }^{72}$ Thus, had the destitution of asylum seekers not been intended by the government, Lord Brown would have regarded issues of proportionality as relevant to the assessment of whether Article 3 had been violated albeit that, on the facts, he would have regarded the hardship as outweighing the particular policy objectives. ${ }^{73}$ He considered it unnecessary and unhelpful, in any Article 3 case, to have to categorise the State's obligation as negative or positive in

65 ibid.

66 Gezer v Sec of State for the Home Dept [2004] EWCA (Civ) 1730, para.[27].

67 ibid., at para.[29].

68 [2005] 2 AC 296, para.[87].

69 [2005] UKHL 66.

70 ibid., paras.[53] and [77]-[78] respectively.

71 See, in particular, ibid., para.[55] per Lord Hope.

72 ibid., para.[89].

73 ibid., para.[101]. 
order to determine whether it would be permissible to consider issues of proportionality or justification. ${ }^{74}$

\section{Disability-Specific Article 3 Developments in Different Living Environments}

\section{Prisons}

As already mentioned, in assessing whether the minimum level of severity has been attained for treatment or punishment to qualify as "degrading", the court must take into account all the circumstances of the case, including the health, age and sex of the victim. ${ }^{75}$ This stress on the circumstances of the particular victim has been used by judges to require States to pay due regard to any impairments (physical or mental) which a prisoner might have in deciding whether Article 3 has been violated.

In Price $\mathrm{v} U K{ }^{76}$ which is perhaps the most important Article 3 case concerning disabled people, the UK was found to have inflicted degrading treatment on Ms Price by its failure to accommodate the particular needs arising from her impairment. As a result of thalidomide, all four of her limbs were fore-shortened and she had a number of associated health difficulties, including kidney problems. Her refusal to answer questions in County Court debt recovery proceedings resulted in her spending three nights in prison. She was refused permission to take the battery charger for her wheelchair to prison; she had to spend the first night in a cell which was dangerously cold for her and contained a bed she was unable to use; she had to be assisted in using the toilet by male staff (having been left sitting on the toilet for three hours on one occasion until she gave up hope of being assisted by a woman); and, at the end of her sentence, she required catheterisation due to lack of fluid and to urine retention caused by difficulties in using the toilet facilities.

The ECtHR ruled that Ms Price's Article 3 rights had been infringed, observing that:

"There is no evidence in this case of any positive intention to humiliate or debase the applicant. However, the Court considers that to detain a severely disabled person in conditions where she is dangerously cold, risks developing sores because her bed is too hard or unreachable, and is unable to go to the toilet or keep clean without the greatest of difficulty, constitutes degrading treatment." ${ }^{\prime 7}$

Judge Greve, who delivered a separate concurring opinion, added that:

74 ibid., paras.[90]-[92].

75 Ireland v UK Series A no. 25 (18 January 1978), para.162.

76 (2001) 34 EHRR 1285. For a similar decision in the UN context, see, Hamilton v Jamaica, communication No 616/ 1995, views adopted by the Human Rights Committee on 28 July 1999 (CCPR/C/66/D/616/1995); discussed in T. Degener, "Disability and Freedom: The International Covenant on Civil and Political Rights" in G. Quinn and T. Degener (eds), Human Rights and Disability - the current use and future potential of United Nations human rights instruments in the context of disability (n.3 above), para.4.1.4.

77 ibid., at para.30. 
"In a civilised country like the United Kingdom, society considers it not only appropriate but a basic humane concern to try to ameliorate and compensate for the disabilities faced by a person in the applicant's situation. . . . The applicant's disabilities are not hidden or easily overlooked. It requires no special qualification, only a minimum of ordinary human empathy, to appreciate her situation and to understand that to avoid unnecessary hardship - that is, hardship not implicit in the imprisonment of an able-bodied person - she has to be treated differently from other people because her situation is significantly different." 78

According to other Article 3 cases, the illness or impairment of a prisoner may, on occasion, require that they be removed from the mainstream prison environment, either by being released or by being transferred into other conditions (such as those of a hospital). Thus, in Mouisel v France, ${ }^{79}$ the ECtHR held that Article 3 had been contravened by the continued detention of a prisoner suffering from leukaemia and undergoing chemotherapy. On his frequent trips to the hospital for treatment he was chained and handcuffed. He alleged that during the chemotherapy sessions his feet had been chained and one of his wrists handcuffed to the bed. He also alleged that, following his attempt to reduce the pain of the treatment by altering the speed of the drip, prison guards physically restrained him and dragged him through the hospital corridors by his chains.

Similarly, in Napier $\mathrm{v}$ Scottish Ministers, ${ }^{80}$ Lord Bonomy ruled that the detention of a prisoner, who had eczema, in the conditions which then existed in the mainstream prison environment constituted degrading treatment. Robert Napier had been required to spend between twenty and twenty-three hours a day in his cell; to share that cell with a series of cellmates even though it was designed for only one; and, most significantly, had been granted extremely limited access to washing and toilet facilities. The "slopping out" regime to which Napier was subjected meant using a bucket or bottle in the cell instead of a toilet, emptying these receptacles alongside other prisoners in chaotic conditions, and having extremely limited opportunities to wash: so limited that it was impossible for Napier to take adequate care of his skin which consequently became infected, ulcerated and flaky. Interestingly, though Lord Bonomy regarded the existence of Napier's eczema as "crucial" 81 to the success of his Article 3 claim, he never described him as "disabled" and made no reference to the Price decision. This illustrates the ability of Article 3 to respond to the particular circumstances of disabled people without imposing on them any threshold requirement in the form of a specific definition of "disability". It thus stands in refreshing contrast to the Disability Discrimination Act 1995 where failure to satisfy the

78 ibid.

79 Application No. 67263/01 (14 November 2002).

80 [2004] SLT 555. See, for further discussion of this case, A. Lawson and A. Mukherjee, "Slopping Out in Scotland: The Limits of Degradation and Respect" [2004] EHRLR 645.

81 ibid., at para.[76]. 
definition of disability has caused more cases to flounder than has any other reason. ${ }^{82}$

As well as demonstrating the need, on occasion, to modify regimes or conditions for disabled prisoners, these cases illustrate the need to provide them with adequate medical care. This requirement is also, and more directly, demonstrated by Keenan $\mathrm{v} U K .^{83}$ Keenan was known to have schizophrenia and to be a suicide risk. Following a change in medication, he assaulted two prison guards and, without proper psychological assessments of the impact of the move on his health, was sent from the hospital block to the punishment block for a period of solitary confinement. During this time, Keenan committed suicide. The lack of adequate medical records covering the period in question indicated that, during it, his condition had not been adequately monitored. Similarly, in McGlinchey $\mathrm{v} U K,{ }^{84}$ it was found that Article 3 had been breached by a failure to provide appropriate care to a prisoner who had severe asthma and was dying from heroin addiction.

The need to provide adequate medical care to prisoners also underlies the decision in $D$ v $U K^{85}$ which, as mentioned above, concerned the deportation of a prisoner dying of AIDS from the UK to St Kitts where he would have had no prospect of receiving medical care or family support. However, the fundamental issue in $D$ and other such cases (which are not confined to the prison context) is the extent to which Article 3 operates to prevent States applying their general immigration policies to deport sick or disabled people to countries in which they are unlikely to receive adequate care. ${ }^{86} \mathrm{~A}$ detailed examination of such cases would therefore stray beyond the scope of this article, the prime focus of which is the relevance of Article 3 to the lives of disabled people who are entitled to remain living in the UK.

In the prison context, then, Article 3 cases have played an important role in establishing minimum acceptable standards for the treatment of disabled people. They have drawn attention to the additional suffering which a regime may cause to a disabled person and stressed the importance of making appropriate adjustments in order to take account of their particular

82 S. Leverton, Monitoring the Disability Discrimination Act 1995 (Phase 2) (London: Stationary Office, 2002), 14.

83 (2001) 33 EHRR 38.

84 Application No. 00050390/99 (29 April 2003). See also, $R$ v Sec of State for the Home Dept, exp Wright and Bennett [2001] EWHC (Admin) 520.

85 (1997) 24 EHRR 423.

86 The issue was considered in some depth by the House of Lords in the non-prison case of $N(F C)$ v Sec of State for the Home Dept [2005] 2 AC 296. According to it, the deportation of a would-be immigrant, who had a serious illness for which they were receiving medical care in the UK, was likely to ground an Article 3 violation only where that person was actually in the terminal stages of the disease at the time of the application and only then if the country to which they would otherwise be deported offered no relevant medical care at all. Thus, in $N$, Article 3 was not held to be violated by the deportation to Uganda of a woman who had advanced AIDS, but whose condition had been stabilised by treatment in the UK, where medical treatment was technically available in Uganda (despite the fact that it was extremely unlikely that the claimant would be able to access that treatment in practice and that, without it, her life expectancy would be reduced from decades to a year or two). 
circumstances. An undoubtedly significant factor in these cases is the relative powerlessness of prisoners over their environment and the high degree of control which the State exercises over all aspects of their lives. Although this factor is also present (to some degree) where disabled people are required to live in residential institutions in order to receive adequate care, its absence from scenarios in which disabled people live at home seems (as will be considered below) to have contributed to an unwillingness to extend Article 3 protection to such cases.

\section{Residential Institutions}

\section{Inadequate Care}

Many disabled people continue to live in residential institutions, such as psychiatric hospitals, homes for the elderly and other long-stay institutions. Indeed, although government policy is to encourage independent living in the community, there is some indication that the number of disabled people living in institutional care increased between 1997 and 2002. ${ }^{87}$ While some of these institutions undoubtedly provide exemplary regimes, many do not. ${ }^{88}$ Jenny Watson's 2002 report $^{89}$ documents disturbing conditions in a number of such institutions. It includes accounts of practices and policies which appear to reflect a complete absence of concern for the dignity and wellbeing of residents. The following is an example:

"An agency worker told us about going into a home at breakfast time. She was instructed to get the residents up and onto their commode. She was then told to feed them breakfast. When she started to get the residents off their commodes first she was stopped. The routine of the home was that residents ate their breakfast while sitting on the commode and the

87 Cabinet Office Strategy Unit Improving the Life Chances of Disabled People (London: Stationary Office, 2005), para.4.4.

88 For a shocking example drawn from elsewhere in Europe, see Amnesty International's 2002 report on Bulgaria. It contains the following account:

"In the Sanadinovo home for mentally disabled women, those who 'misbehaved' were held in a cage made of two brick walls with iron bars and wire on the remaining two sides. In October, an AI delegate witnessed six women being held in this $3 \mathrm{~m} \times 1.5 \mathrm{~m}$ space. They looked withdrawn and vacant and appeared nonaggressive. The cage was full of urine and faeces and the women were covered in filth. One woman was naked from the waist down and many sores were visible on her skin. It was not possible to establish how long anyone would be subjected to this form of seclusion as no records of this appeared to be maintained." See "Amnesty International: Europe - Bulgaria 2002" at http://web.amnesty.org/web/ ar2002.nsf/eur/bulgaria (last visited 3 August 2005). See also Amnesty International press release "Bulgaria: Disabled women condemned to 'slow death", AI-index: EUR 15/002/2001; and, more generally, O. Lewis, "Mental Disability Law in Central and Eastern Europe: Paper, Practice, Promise" (2002) 8 Journal of Mental Health Law 293.

89 Something for Everyone: The impact of the Human Rights Act and the Need for a Human Rights Commission (London: British Institute of Human Rights, 2002). See also, H. Brown, Safeguarding Adults and Children with Disabilities Against Abuse (n.11 above), especially paras.2.1.3 and 3.5. 
ordinary men and women who worked there had come to accept this as normal." ${ }^{90}$

The general tenor of the accounts documented in this report is captured by the following extract:

"In relation to care homes, people have their time organised for them. The sort of things you want to do in your own home can't happen. Things like transport provision are usually for the convenience of the provider, not the user. We know of cases [in residential settings] where people have been left in their own excrement, where they are put to bed at five o'clock in the evening, where they are not allowed to watch TV in the evenings." 91

Rowena Daw, writing in 2000, provides another account of the type of suffering and degradation which may be experienced by a disabled person living in residential care:

"A deaf woman who signed was a long-term resident in a residential home. She was not given communication support because her notes explaining her need were lost. Lacking the means of communication she developed behavioural difficulties and was then misdiagnosed as of low intelligence. She was kept in total isolation for 30 years until the home was closed down and the truth was discovered. She had by then lost her ability to sign." $" 92$

Living conditions in such institutions, then, have resulted in intense suffering and humiliation for a considerable number of disabled people. In the words of Gerard Quinn, writing in the international context:

"It is undeniable that torture, and the less severe but equally abominable phenomena of cruel, inhuman or degrading treatment or punishment, have lurked quietly behind the closed doors of mental and physical disability institutions." 93

The requirements of Article 3, it is suggested, should not be applied any less strictly in this context than in that of prisons. Reference is often made to the peculiar vulnerability of prisoners to abuse, given the control imposed on all aspects of their lives. ${ }^{94}$ This vulnerability also characterises disabled residents living in institutions providing them with care on which they are

90 ibid., at 49. See also A. Clarke and L. Bright, Showing Restraint: Challenging the Use of Restraint in Care Homes (London: Counsel \& Care, January 2002).

91 J. Watson, Something for Everyone: The Impact of the Human Rights Act and the Need for a Human Rights Commission (n 89 above), 37 (quoting from the submission of Andy Rickell, British Council of Disabled People).

92 The Impact of the Human Rights Act on Disabled People (London: Disability Rights Commission and Royal National Institute for Deaf People, 2000), 52.

93 G. Quinn, "The Integrity of the Person: The Convention Against Torture and Other Cruel, Inhuman or Degrading Treatment or Punishment and Disability" (n 3 above), para.6.1.

94 See, e.g. Anguelova v Bulgaria Application No 38361/97 (13 June 2002), para.110; and S Livingstone, T. Owen and A. MacDonald, Prison Law (Oxford: Oxford University Press, 2003) para.2.01. 
totally dependent. Indeed, in psychiatric hospitals, many of them (like prisoners) will be there expressly against their will, and in other institutions, many will be there only because there is no alternative. This vulnerability was recognised by the ECtHR in Herczegfalvy v Austria ${ }^{95}$ :

"The Court considers that the position of inferiority and powerlessness which is typical of patients confined in psychiatric hospitals calls for increased vigilance in reviewing whether the Convention has been complied with."

Thus it seems that residents of these institutions would, in theory, be able to use Article 3 to call for at least the same minimal level of care as that required in the prison cases. Indeed, it has been suggested by the Court of Appeal $^{96}$ that inadequate or inappropriate conditions of detention might be more likely to amount to inhuman or degrading treatment in the case of a patient than in that of a prisoner. This is because the detention of a prisoner is an end in itself whereas that of a patient is a means to an end: the end being the provision of care and, in some cases, the restoration of health. Article 3, it was suggested, may be more likely to be engaged where the conditions in question undermine the very purpose of the detention.

Nevertheless, the suffering of disabled people in residential institutions has given rise to surprisingly few Article 3 cases. ${ }^{97}$ Possible explanations for this emerge clearly from even the most cursory glance through Jenny Watson's report. Residents who do complain about inadequate care are sometimes faced with expulsion from the home: an extremely daunting prospect for those with no real alternative accommodation and one likely to deter the bringing of complaints. ${ }^{98}$ Fear of consequences other than expulsion, such as victimisation by care providers, may also prove influential. ${ }^{99}$ Even where complaints are made, the evidence of disabled people (particularly those with learning difficulties or mental illness) is often regarded as insufficiently cogent to found disciplinary actions or criminal proceedings. ${ }^{100}$

95 (1992) 15 EHRR 437, paras.82 and 110.

$96 \quad R$ v Mersey Care NHS Trust, ex p Munjaz, $R$ v Airedale NHS Trust, ex p S [2003] 3 WLR 1505, para.[56].

97 See generally, L. Clements and J. Read, "The Dog that Didn't Bark: The Issue of Access to Rights under the European Convention on Human Rights by Disabled People" in A. Lawson and C. Gooding (eds.), Disability Rights in Europe: From Theory to Practice (Oxford: Hart Publishing, 2005); and G. Quinn, "The Integrity of the Person: The Convention Against Torture and Other Cruel, Inhuman or Degrading Treatment or Punishment and Disability" (n.3 above), para.61.

98 This is illustrated by the following extract (Something for Everyone: The Impact of the Human Rights Act and the need for a Human Rights Commission (n.89 above), 48): "[X] has been asked to leave her residential care home because she complained about a member of staff who would not attend to her in the night. She wanted to go to the toilet so she rang the buzzer but the staff member didn't come for about half an hour, by which time it was too late. The care worker left her in her wet night clothes, took the buzzer from her and threw it across the room".

99 K. Simons, I'm Not Complaining, but . . . (York: Joseph Rowntree Foundation, 1995).

100 This is illustrated by the following extract (Something for Everyone: The Impact of the Human Rights Act and the Need for a Human Rights Commission (n.89 above), 41, quoting from the submission of Rachel Hurst, Disability Awareness in Action): "We've got a case of a young black man, who's severely autistic, 


\section{Unwanted Medical Treatment}

An issue which has come before the ECtHR and UK courts on a number of occasions is the question of whether medical treatment or force-feeding, provided against the will of a person confined in an institution and lacking the capacity to consent, constitutes inhuman or degrading treatment. The leading case is Herczegfalvy v Austria. ${ }^{101}$

Mr Herczegfalvy, who was a psychiatric patient and lacked full mental capacity according to Austrian law, was isolated from other residents and attached with handcuffs and other straps to a security bed for a fortnight. Despite his struggles and protests (which resulted in him suffering the loss of teeth, broken ribs and bruising) $)^{102}$, food and neuroleptic medication were administered. He argued that this treatment had contributed to the worsening of his condition and constituted inhuman and degrading treatment contrary to Article 3. The Austrian government argued that the treatment in question had been necessary in order to preserve his health, pointing out that:

"[It] was only his resistance to all treatment, his extreme aggressiveness and the threats and acts of violence on his part against the hospital staff which explained why the staff had used coercive measures including the intramuscular injection of sedatives and the use of handcuffs and the security bed. These measures had been agreed to by Mr. Herczegfalvy's curator [guardian], their sole aim had always been therapeutic, and they had been terminated as soon as the state of the patient permitted this." 103

The Court, in ruling that there had been no breach of Article 3, laid down the "general rule" that "a measure which is a therapeutic necessity cannot be regarded as inhuman or degrading" and that, consequently, established principles of medicine would be "in principle decisive in such cases". ${ }^{104}$ It added, however, that: "The Court must nevertheless satisfy itself that the medical necessity has been convincingly shown to exist". ${ }^{105}$ In $R \mathrm{v} M$ and Others, ex parte $N,{ }^{106}$ the Court of Appeal stressed that the "convincingly shown" requirement imposed a high standard of proof on the State but that it should not be equated with the criminal standard of "beyond reasonable doubt".

we've got medical evidence that he was beaten black and blue in the home, his grandmother took him away. The CPS said initially they would take the case on, but then they withdrew, because they said he couldn't give evidence".

101 (1992) 15 EHRR 437. See also X v Federal Republic of Germany (1984) 7 EHRR 152 where the force-feeding of a prisoner on hunger strike was held not to violate Article 3; and $R$ v Responsible Medical Officer, $\operatorname{Dr} G$ and $\ldots D r \mathrm{~W}$, ex $p$ $P S$ [2003] EWHC (Admin) 2335 where the provision of medical treatment to a competent patient against their will was held not to contravene Article 8.

102 Para.31.

103 Para.81.

104 Para.82.

105 ibid.

106 [2003] 1 WLR 562, paras.[17]-[18]. 
In $R$ v Dr $S$ and Others, ex parte $B,{ }^{107}$ Charles $\mathrm{J}$ considered the application of Herczegfalvy to UK law in some depth. In so doing he reached two conclusions, both of which facilitate the application of unwanted medical treatment to people detained under the Mental Health Act 1983 (MHA). First, he held that Herzegfalvy did not require a therapeutic necessity to be demonstrated in all cases of unwanted medical treatment. Such a necessity would be required only where the proposed treatment was likely to cause the patient suffering so severe as to engage Article 3. In decisions as to which side of this line a case might fall, according to Charles $J$, the evidence of the doctor caring for the patient (and presumably wishing to apply the treatment) would be of particular significance. ${ }^{108}$ Second, he held that although the ECtHR in Herczegfalvy had been concerned with cases in which patients were "entirely incapable of deciding for themselves", ${ }^{109}$ the principles it laid down were also applicable to cases in which patients were capable of deciding for themselves but to whom Part IV of the Mental Health Act 1983 authorised the administration of treatment contrary to their wishes. ${ }^{110}$

The therapeutic necessity test itself is not unproblematic, as has been convincingly argued by Oliver Lewis. ${ }^{111} \mathrm{He}$ describes it as "highly deferential" and draws attention to the difficulty which people deemed to lack mental capacity are likely to face in disproving medical necessity. Persuading judges to trust their testimony where it contradicts that of professional doctors is not likely to be easy. This problem is exacerbated by the decision in $B$ that in some cases of unwanted medical treatment, to be identified largely by the responsible doctor, there will be no need to show that there was any therapeutic necessity for the intervention. It may also be intensified by the fact that, in the ECtHR, a violation of Article 3 must generally be established beyond reasonable doubt, ${ }^{112}$ (although there is now some UK authority to the effect that the relevant standard is the usual civil standard of a balance of probabilities). ${ }^{113}$ Against this background, as Lewis notes, it is disturbing to learn that in recent years, in a number of European countries (though admittedly not the UK), doctors have authorised practices such as the electroconvulsive therapy of mentally-ill people without anesthesia or muscle relaxants ${ }^{114}$ and their confinement in caged-beds (sometimes for months or years). ${ }^{115}$ It would not be difficult to challenge the

107 [2005] EWHC 1936.

108 ibid., paras.[60]-[70].

109 (1992) 15 EHRR 437, para.82.

110 [2005] EWHC 1936, para.[58]. See also Re B [2005] EWHC 86, paras.[109][112] per Silber J.

111 "Protecting the Rights of People with Mental Disabilities: The European Convention on Human Rights" [2002] 9 European Journal of Health Law 293.

112 See generally Ireland v UK (1978) 2 EHRR 25 paras.160-161.

113 Napier v Scottish Ministers [2005] UKHRR 268.

114 See, e.g. Bulgarian Helsinki Committee Inpatient psychiatric care in Bulgaria and human rights (Sofia: Bulgarian Helsinki Committee, 2001) reporting that this practice was carried out in at least eight psychiatric institutions in Bulgaria and that it is prescribed by twenty per cent of Bulgarian psychiatrists.

115 See G. Gombos, E. Kismrdi, K. Petr, The Human Rights of Patients in Social Care Homes for the Mentally Ill (Budapest, Hungarian Mental Health Interest Forum, September 2001) reporting that caged beds were used in eight of the fiftytwo Hungarian institutions studied; see also "Disabled People Padlocked in 
therapeutic necessity of these particular practices as they have been condemned as inhuman and degrading by the Committee for the Prevention of Torture and Inhuman or Degrading Treatment or Punishment (CPT). ${ }^{116}$ Cases in which similarly painful or simply humiliating practices (including, for example, prolonged courses of heavy sedation) have been approved by doctors, but not been subjected to the scrutiny of bodies such as the CPT, are likely to prove more problematic.

\section{Home}

Without appropriate support, or in inappropriate surroundings, disabled people may live in what would generally be regarded as "degrading" conditions even though they are within their own homes. Some examples of the types of difficulties which they may face are provided by Rowena Daw's report for the Disability Rights Commission. ${ }^{117}$ In cases such as $A \mathrm{v} U K^{118}$ and $Z \mathrm{v} U K,{ }^{119}$ it was held that States have a positive obligation to take steps to protect children living in their own homes who are at risk of suffering inhuman or degrading treatment at the hands of people not connected with the State (in those cases parents or step-parents). In both these cases the children concerned were at risk of experiencing inhuman and degrading treatment through violence although, in $Z$, they were also at risk of experiencing it through neglect. There is little doubt that a similar duty would exist where people become vulnerable to the risk of such harm at the hands of others because of disability rather than childhood. There is, on the other hand, some uncertainty as to whether Article 3 imposes any obligation on signatory States to take steps to protect disabled people from the isolation, humiliation, degradation and injury which sometimes result from living in an inaccessible environment or without adequate support. This issue has been considered in two recent English cases which appear to have adopted quite different approaches.

In $R$ v Enfield $L B C$, ex $p$ Bernard, ${ }^{120}$ a restrictive approach to Article 3 was adopted. From June 2000 until October 2002 Mrs Bernard had lived in "deplorable conditions", ${ }^{121}$ with her husband and six children, in a house which had been provided by the Local Authority and which was not accessible to her. Sullivan J took the view that the delay and inefficiency of the Council (which amounted to a breach of its statutory duty to provide suitable accommodation under section 21(1)(a) of the National Assistance Act 1948) had unnecessarily lengthened her ordeal in that house by some twenty months. ${ }^{122}$ Reports drawn up in September 2000 had informed the Authority of her situation and the urgent need to provide her with alternative accommodation, but no action had been taken.

Caged Beds" Disability Tribune (London: Disability Awareness in Action, December 2003/January 2004) reporting on the use of such beds in Slovenia, Hungary, Slovakia, and the Czech Republic.

116 CPT/Inf (1998) 12 para.39; CPT/Inf (2001) 2 para.8.

117 The Impact of the Human Rights Act on Disabled People (n.92 above), 54-55.

118 (1998) 100/1997/884/1096 (23 September 1998).

119 (2002) 34 EHRR 97.

120 [2002] EWHC (Admin) 2282.

121 ibid., at paras.[29] and [30].

122 ibid., at para.[31]. 
Mrs Bernard's electric wheelchair could not be taken into the house and, as a result, she spent most of her waking time sitting in a shower chair which caused her pain. She was unable to reach the bathroom without help from her husband, who was not always available. Consequently, she soiled herself several times each day: a situation which, according to her husband, she found "depressing", "demeaning" and "very humiliating". ${ }^{123}$. She attempted to reduce this problem by drinking less, which exacerbated her diabetes. She could not reach or use the kitchen and was therefore unable to cook for herself and her family. She was unable to answer the door or to leave the house independently. She was confined to the lounge which, at night, became a bedroom for herself and her husband and their two youngest children. Though the judgement does not contain information about her falls and injuries after the first few months in the house, it does indicate that, by September 2000, she had fallen four times, injuring her breast and her thumb. Not surprisingly, the social worker's report compiled in that month drew attention to the fact that:

"Mrs Bernard feels very unsafe at home. Occasionally she is left alone with the two youngest children when her husband has to collect the other children from school. At these times she feels particularly concerned should there be an accident/emergency she could not raise an alarm or help the children. . . Generally feels very vulnerable in her situation." 124

Although Mrs Bernard's case succeeded under Article 8, and indeed constituted a landmark development on the issue of damages under section 8 of the Human Rights Act 1998, it did not succeed under Article 3. Sullivan J acknowledged that the conditions in which she had lived were deplorable and that they had deprived her of her ability "to operate . . . as a person in her own right" and of her "dignity as a human being". ${ }^{125}$ They were, in his view, conditions which were likely to have caused a less resilient person to have become mentally or physically ill. ${ }^{126}$ Nevertheless, Sullivan J found that the minimum level of severity threshold had not been crossed. ${ }^{127}$

This aspect of Sullivan J's decision is extremely disappointing. He explained it on the basis that cases such as Price, in which Article 3 was found to have been violated despite the lack of any intention to humiliate or debase, were concerned with the rights of prisoners and must be treated "with great caution outside the prison gates". Prisoners were deliberately subjected, against their will, to regimes ordained by prison authorities. Mrs Bernard, on the other hand, had been living in her own home, surrounded by her family, and the deplorable conditions which she had had to endure had not been "deliberately inflicted" upon her or the result of a "positive decision". They were, rather, the result of the Council's "failure to act" and of its "corporate neglect". 128

23 ibid., at para.[20].

124 ibid., at para.[7].

125 ibid., at para.[33].

126 ibid., at para.[46].

127 ibid., at para.[28].

128 ibid., at paras.[28]-[29]. 
Sullivan J's analysis of this issue is brief and also somewhat confusing. The confusion arises in part because he did not differentiate between two separate, though inter-related, questions: first, whether the suffering had reached the minimum Article 3 threshold of severity and, second, whether the State should be held responsible for that suffering. ${ }^{129}$ While Sullivan J ruled that Mrs Bernard's suffering did not satisfy the threshold requirement, it is unclear whether his reasons for this observation relate primarily to this first issue or whether they, in fact, relate to the question of State responsibility for the suffering concerned (the second question).

In relation to the first issue (that of severity of suffering), the fact that it occurred in a home environment is undoubtedly relevant. The fact that suffering is experienced in an institution, such as a prison, into which the victim is forced to enter and over which they have no control, should undoubtedly be regarded as an exacerbating factor. ${ }^{130}$ To this extent, Sullivan J's differentiation between Price and Bernard is entirely appropriate. His consideration of whether Mrs Bernard's suffering was sufficiently severe to cross the Article 3 threshold, however, should not have stopped here. To regard the absence of this factor as necessarily decisive would be to fail to acknowledge the extent of the degradation and humiliation which may be experienced by disabled people inside their own homes. Mrs Bernard, for instance, was effectively imprisoned in a shower chair in her living-room for over two years; her husband holding the key. When he was not there, she was trapped and frightened: unable to leave the house or to use the bathroom. She was required to undergo the indignity of soiling herself (and often the carpet) two or three times a day in the presence of her young children and suffered physical injuries as a result of futile attempts to reach the bathroom and avoid this indignity. Furthermore, as Sullivan J recognised, her ordeal was an extremely protracted one (lasting for twenty months longer than necessary) as opposed to the week long ordeal endured by Ms Price. It is arguable that, even though Mrs Bernard was not a prisoner as such, her ordeal amounted to a form of imprisonment. It is also certainly arguable that it involved "actual bodily injury or intense physical or mental suffering" or that it humiliated or debased her, "showing a lack of respect for, or diminishing . . . her human dignity or arouse[d] feelings of fear, anguish or inferiority capable of breaking [her] moral and physical resistance". ${ }^{131}$

It is a great pity that the second issue, that of state responsibility for suffering of the type endured by Mrs Bernard, was not considered more fully by Sullivan J. He indicated that Article 3 was not violated because the suffering had been caused by neglect rather than by a deliberate act. As mentioned above, it is not entirely clear whether this point was intended to address the issue of the severity of Mrs Bernard's suffering or whether it was intended to address the issue of state responsibility. Assuming it was directed at the

129 See, e.g. Gezer v Sec of State for the Home Dept [2004] EWCA (Civ) 1730, para.[25] per Laws LJ for a clear identification of these two separate questions.

130 For recognition of the importance of this distinction, see $R \mathrm{v} D P P$, ex p Pretty [2002] 1 AC 800, para.8 per Lord Bingham and Keenan v UK (2001) 33 EHRR 38 , para. 90 .

131 Pretty v UK (2002) 35 EHRR 1, para.52. 
latter, it is an inadequate explanation for a refusal to hold the Council liable for an Article 3 violation.

In certain circumstances, as explained above, the failure of a public authority to take action may well violate Article 3. The Bernard case, being one in which the suffering was caused by circumstance rather than by violence, would certainly fall towards the outer edge of category (b) of Laws LJ's spectrum. Various features of the case, including the intensity of Mrs Bernard's suffering, its duration and the fact that it resulted from a grossly negligent failure to implement existing policy, would seem to demand a consideration of the breadth of $Z \mathrm{v} U K^{132}$ and the question of whether the State's failure to act was within the margin of judgment granted to it by Article 3 - a question which would require consideration of its impact on Mrs Bernard and the consequences of the finding of a violation on the general population. Such questions deserve careful scrutiny and it is to be hoped that, in any future similar case, they will receive it. It should perhaps be stressed that a finding of an Article 3 violation in cases such as Bernard need not oblige States to introduce a basic minimum level of provision for disabled people. ${ }^{133}$ As in $\mathrm{Z}$, what is at issue is the impact on a particular individual of the failure of a State to implement its accepted policy.

The second of the recent first instance cases to have considered Article 3 in the context of disabled people living in their own home is $R$ v East Sussex County Council, ex parte $A$ and $B .{ }^{134}$ In this case a more generous approach than that in Bernard appears to have been adopted. Its likely impact is reduced, however, by the fact that its analysis of the Article is extremely brief, is very much obiter and contains no reference to the Bernard decision.

The East Sussex case concerned two sisters in their twenties, both of whom had profound physical impairments and learning difficulties. Because of the Council's "no lifting" policy (which forbade its staff from lifting people such as A and B manually), the sisters became virtual prisoners in their parents' home. The blanket "no lifting" policy, combined with the lack of mechanical lifting devices, meant that they were unable to access toilets and other facilities outside their home. The introduction of this policy was therefore challenged.

Though not required to decide whether Article 3 had been violated, Munby J indicated that in this type of case the Article might be engaged where, for instance, failing to lift A or B manually might result in them remaining "sitting in bodily waste or on the lavatory for hours, unable to be moved". ${ }^{135}$ He drew attention to the fact that the standards required by Article 3 increased as social standards improved and observed that:

"The concept of human dignity may be the same as ever, but the practical standards which require to be met are not. Changes in social standards demand better provision for the disabled if their human dignity is not to be impaired."136

132 [2002] 34 EHRR 97.

133 See the text accompanying nn.23-26 above.

134 [2003] EWHC (Admin) 167.

135 ibid., at para.[114].

136 ibid., at para.[98]. 
In the UK, then, there is currently some uncertainty as to how Article 3 should be applied in cases where disabled people, not living in prisons or other residential institutions, suffer humiliation, indignity and discomfort as a result of inadequate support. The two cases which have considered the issue are both first instance and point in different directions. If there is indeed to be no Article 3 violation in a case such as Bernard, it is virtually impossible to imagine any circumstances in which disabled people living in their own homes would be able to establish an Article 3 violation in the absence of a deliberate intent that they should suffer. The issue is an important one, particularly if disabled people are to be permitted, and even encouraged, to move out of institutions and into their own homes. ${ }^{137}$ It requires much closer judicial scrutiny than it has received to date.

\section{The Universality of Article 3}

The question of whether Article 3 applies where the disputed treatment is inflicted on a person who is unaware of, or unable to appreciate, any consequent suffering or degradation has not yet directly confronted the ECtHR. In recent years, however, it has troubled UK courts on a number of occasions and resulted in conflicting decisions. The context in which this question has arisen is that of disputes about the withdrawal of artificial nutrition and hydration from patients in a "persistent vegetative state". ${ }^{138}$ Significantly, however, it does have relevance to, and implications for, people who are conscious and even active but who have mental impairments or illnesses which render them unable to appreciate that what is happening to them would conventionally be regarded as humiliating or degrading.

In the pre-Human Rights Act case of Airedale NHS Trust $\mathrm{v}$ Bland, ${ }^{139}$ the House of Lords ruled that it would be lawful for doctors to withdraw treatment (which was held to include artificial nutrition and hydration) from a patient if the treatment in question was considered by a responsible body of medical opinion to be no longer in the best interests of that patient. Tony Bland, who had been in a persistent vegetative state for three years after having been trampled on at the Hillsborough football stadium, was considered to have effectively no interests at all. It was therefore lawful to remove the tubes which supplied him with food and water even though, after a period of about two weeks, this would inevitably result in his death.

The Bland decision has generated much debate. Concerns expressed by commentators relate to the influence of medical judgments that some lives

137 Cabinet Office Strategy Unit Improving the Life Chances of Disabled People (n.87 above), chap.4. See also Article 15 of the UN Draft Comprehensive and Integral International Convention to Protect and Promote the Rights and Dignity of Persons with Disabilities, available at www.un.org/esa/socdev/enable/rights /ahcwgreporta19.htm (last visited on 30 September 2005) which would confer on disabled people the right to choose to live in their communities with appropriate support and prevent States from requiring them to live in institutions.

138 Although this term is now in general use, it is unpopular with many doctors and with patients' associations because of its tendency to equate the people concerned with vegetables. For further discussion, see A. Grubb, P. Walsh and P. Lambe, "Reporting on the Persistent Vegetative State in Europe" [1998] Med LR 161, 173.

139 [1993] AC 789. 
are not worth living in decisions to end life; ${ }^{140}$ to the possibility of misdiagnoses of a persistent vegetative state and mistaken prognoses as to the likelihood of recovery; ${ }^{141}$ and to the possible extension of Bland beyond people in persistent vegetative states to people with other forms of physical or mental impairment. ${ }^{142}$ Although these issues are of supreme relevance to disabled people, they fall outside the ambit of Article 3 and therefore of this discussion.

The relevance of Bland to this article lies in the argument, to which it has given rise, that the withdrawal of food and water from a person may constitute inhuman or degrading treatment contrary to Article 3. This argument was raised and rejected in NHS Trust A $v$ Mrs M, NHS Trust B v Mrs $H .{ }^{143}$ Butler-Sloss $\mathrm{P}$, after referring to the need for "degrading treatment" to arouse feelings of fear, anguish or inferiority in the victim, declared herself to be "satisfied that Article 3 requires the victim to be aware of the inhuman and degrading treatment which he or she is experiencing or at least to be in a state of physical or mental suffering". ${ }^{144}$ Because the two people concerned in that case were in persistent vegetative states, they had "no feelings and no comprehension of the treatment accorded to [them]"145 and Article 3 could therefore not apply.

This conclusion is alarming. ${ }^{146}$ It raises the difficult question of exactly how much consciousness or awareness a person must have in order to enjoy the protection of Article 3. Would its protection extend, for instance, to a person who is fully conscious but who, because of a mental impairment, does not interpret what is happening to them as a humiliation or degradation?

Butler-Sloss P's ruling places disabled people who are unable to appreciate the humiliating, degrading or even painful consequences of particular treatment (whether because they are in a persistent vegetative state or because they have some lesser degree of mental impairment), completely beyond the protective scope of Article 3. That Article would not be infringed if, for instance, an insensate or unaware patient were used as a

140 See, e.g. J. Keown, "Restoring Moral and Intellectual Shape to the Law After Bland" (1997) 113 LQR 481, especially at 492-496; J.M. Finnis, "Bland: Crossing the Rubicon" (1993) 109 LQR 329.

141 See, e.g. J. Keown, "Restoring Moral and Intellectual Shape to the Law After Bland" (1997) 113 LQR 481, 498.

142 See, e.g. G.T. Laurie and J.K. Mason "Negative Treatment of Vulnerable Patients: Euthanasia by any other Name?" [2000] Juridical Review 159; J. Keown, "Life and Death in Dublin" [1996] CLJ 6. For an example of a decision which has authorised the removal of artificial nutrition and hydration from patients who have some degree of cognitive functioning, see In the Matter of a Ward of Court [1995] 2 ILRM 410. See, for discussion of 'slippery slope' arguments, S.W. Smith, "Evidence for the Practical Slippery Slope in the Debate on Physician-Assisted Suicide and Euthanasia" [2005] Med LR 174.

143 (2001) 58 BMLR 87. The same conclusion was reached, obiter, in A National Health Service Trust v D [2000] 2 FLR 677 per Cazalet J.

144 ibid., at para.[49].

145 ibid.

146 For cogent criticism of the reasoning, see A. Maclean, "Crossing the Rubicon on the Human Rights Ferry” [2001] 64 MLR 775, 789-792. 
sideboard ${ }^{147}$ or if they were "treated as a sex object or thrown, living, into the hospital rubbish". ${ }^{148}$ It is a conclusion which does not sit easily with the observation of the ECtHR in Herczegfalvy that the "position of inferiority and powerlessness which is typical of patients confined in psychiatric hospitals calls for increased vigilance in reviewing whether the Convention has been complied with". ${ }^{149}$ It is a conclusion which fails to acknowledge that "the degradation of an incapacitated person shames us all even if that person is unable to appreciate it". ${ }^{150}$ It is a conclusion which refuses to accept that human rights are universal: to be conferred on every human being simply by virtue of their humanity.

The issue was raised again at first instance in $R$ v General Medical Council, ex $p$ Burke $e^{151}$ where it was described by Munby $\mathrm{J}$ as "a point of absolutely fundamental importance". ${ }^{152} \mathrm{He}$ stressed the significance of the Convention's role in protecting the human dignity of disabled people, whom he considered to be particularly vulnerable to abuse, ${ }^{153}$ and drew support from observations made in Keenan v $U K^{154}$ and Pretty $\mathrm{v} U K^{155}$ to conclude that the approach of Butler-Sloss P had been "wrong". ${ }^{156}$ In Keenan, the ECtHR had noted that, though severity of suffering had been a significant issue in many of the Article 3 cases, "there are circumstances where proof of the actual effect on the person may not be a major factor", such as in the case of a mentally-ill person who is incapable of "pointing to any specific ill-effects". ${ }^{157}$ In Pretty, degrading treatment had been described as treatment which either "humiliates or debases an individual, showing a lack of respect for, or diminishing, his or her human dignity" or which arouses in him or her feelings of fear, anguish or inferiority. ${ }^{158}$

Munby $\mathbf{J}$, then, ruled that treatment inflicted on a person unable to appreciate suffering may breach Article 3. The victim's awareness and experience of suffering were relevant, but not essential, factors in the determination of whether the Article had been infringed. His reasoning on this point is clearly set out in the following passage:

"In my judgment treatment is capable of being "degrading" within the meaning of Article 3, whether or not it arouses feelings of fear, anguish or inferiority in the victim. It is

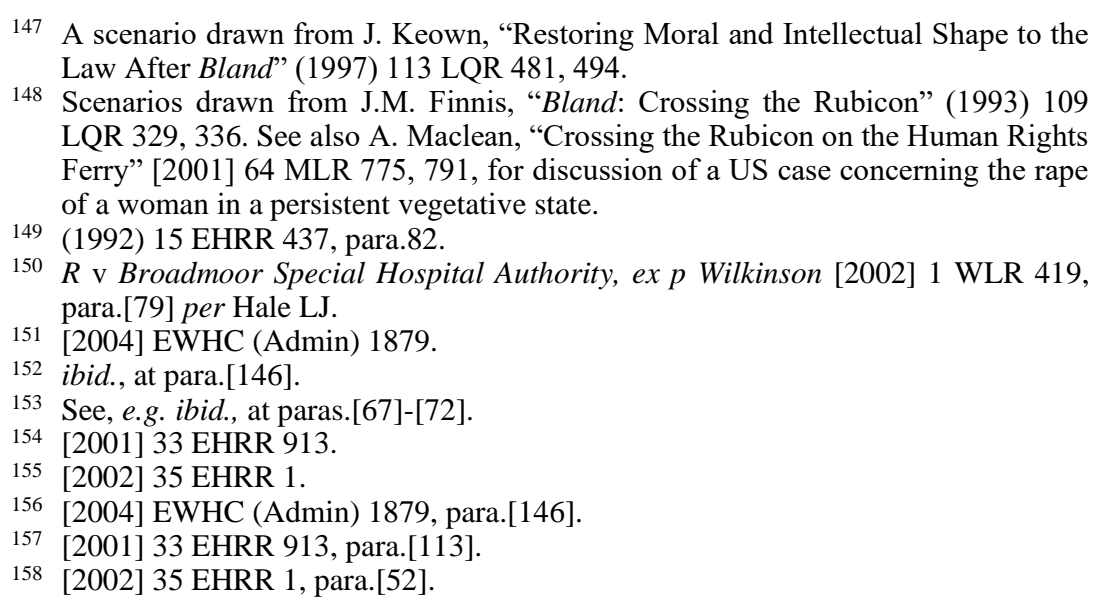


enough if judged by the standard of right-thinking bystanders ... it would be viewed as humiliating or debasing the victim, showing a lack of respect for, or diminishing, his or her human dignity."159

This passage, it is suggested, merits a prominent position in the jurisprudence of Article 3. Regrettably, however, this does not appear to be its destiny. The Court of Appeal in Burke ${ }^{160}$ did not address the issue of the applicability of Article 3 to people lacking awareness of suffering or degradation; clearly considering it to be a matter on which the Court was not required to provide any direction. Their Lordships stated that it would be 'inappropriate' to allow Munby J's judgement, which was severely criticised for its detailed consideration of issues not directly raised by the facts of the case, ${ }^{161}$ to be "seized on and dissected by lawyers seeking supportive material for future cases". ${ }^{162}$ They warned that:

"Although we have said that a great deal in the body of the judgment is uncontroversial, we counsel strongly against selective use of Munby J's judgment in future cases."163

It thus appears that the approach of Butler-Sloss $\mathrm{P}$ in NHS Trust A v Mrs M, NHS Trust B v Mrs $H^{164}$ represents the current law. According to it, the withdrawal of food and water from (or the infliction of any form of treatment or insult upon) people in persistent vegetative states could never amount to an Article 3 violation. Nevertheless, it is worth considering briefly how the withdrawal of food and water from such people would be regarded were Munby J's approach to the applicability of Article 3 to be adopted instead.

In NHS Trust A v Mrs $M$, NHS Trust B v Mrs $H,{ }^{165}$ Butler-Sloss P observed that, should Article 3 be applicable to the two patients with whom she was concerned, it would not be violated by the termination of artificial nutrition and hydration. She referred to the "therapeutic necessity" test laid down in Herczegfalvy and was satisfied that, in the case before her, the proposed withdrawal of treatment had been "thoroughly and anxiously considered by a number of experts in the field" and was "in accordance with the practice of a responsible body of medical opinion". ${ }^{166}$ In Burke, Munby J expressed broad agreement with this approach ${ }^{167}$ but stressed that conceptions of what was dignified or undignified would vary from individual to individual and drew attention to the overriding importance of the right to personal autonomy protected by Article $8 .{ }^{168}$ In assessing whether the withdrawal of artificial nutrition and hydration from an insensate person would infringe Article 3, much would therefore depend on the terms of any advanced directive they

159 [2004] EWHC (Admin) 1879, para.[149].

160 [2005] EWCA (Civ) 1003.

161 ibid., at paras.[19]-[21].

162 ibid., at para.[24]

163 ibid.

164 (2001) 58 BMLR 87.

165 ibid.

166 ibid. at para.49.

167 [2004] EWHC (Admin) 1879, para.[136]

168 ibid., at paras.[66] and [127]. 
had made and their beliefs and values, as well as on their medical condition at the time in question. ${ }^{169}$

The applicability of Article 3 to people unable to comprehend the humiliation or suffering which the treatment in question would otherwise cause them is, as Munby $\mathrm{J}$ recognised, an issue of "absolutely fundamental importance". It is, of course, of importance to people who lack this capacity (or who may do so in the future) and to their families. It is also of importance to society as a whole and to the nature of the Convention's role. If human rights are to be in any meaningful sense "universal", it is vital that Munby J's approach is adopted by higher courts in the UK and, of course, by the ECtHR, in preference to that outlined by Butler-Sloss P.

\section{Conclusion}

Article 3 plays an essential role in the protection of the humanity and dignity of all (or, on the view of Butler-Sloss P in NHS Trust A v Mrs M, NHS Trust $B$ v Mrs $H,{ }^{170}$ nearly all) citizens in signatory States. It is, of course, not the only ECHR article to offer protection and, in many cases, it may be possible to establish a violation of Article 8 in circumstances which would fall short of the severity required by Article 3. It is important, however, that judges and advocates resist any temptation to avoid consideration of Article 3 in cases where it is clear that redress will be available through other means. Article 3, in marking out the most unacceptable instances of State-generated degradation and humiliation, has a powerful declaratory function which should not be overlooked.

It has been said that: "Disability challenges society to live up to its values and sets [human rights] law the task of engineering positive change". ${ }^{171}$ Many of the Article 3 cases discussed here have set about this task with genuine commitment. Nevertheless, in some important respects the Article 3 jurisprudence lends what is, at best, only equivocal support. In particular, on the most fundamental issue of all - the issue of whether certain categories of disabled people are altogether excluded from the protective scope of Article 3 - there is currently uncertainty.

A number of decisions relating to disabled prisoners demonstrate the potential of Article 3 for disabled people. Its focus on the suffering of the particular individual obliges States to respond to the particular circumstances of a disabled person and, on occasion, to treat them differently from others. Such recognition of, and responsiveness to, the needs of a particular individual is crucial to any meaningful notion of respect or dignity. ${ }^{172}$

169 ibid., at para.[176].

170 See the discussion in the previous section of this article.

171 G. Quinn and T. Degener (eds.), Human Rights and Disability - the current use and future potential of United Nations human rights instruments in the context of disability (n.3 above), para.1.0.

172 For further discussion of the concept of dignity, see D. Beyleveld and R. Brownsword, "Human Dignity, Human Rights and Human Genetics" [1998] MLR 661; D. Feldman, "Human Dignity as a Legal Value - Part I" [1999] PL 682; and G. Quinn and T. Degener (eds.), Human Rights and Disability - the current use and future potential of United Nations human rights instruments in the context of disability (n.3 above), chap. 1. 
These prison cases have direct relevance to the treatment of disabled people in other forms of residential institution where a high degree of control is exercised over all aspects of their lives. It is disappointing, however, that there have not been more cases challenging the treatment of disabled people in such institutions. ${ }^{173}$ The dearth of cases should certainly not be regarded as proof that all is well. It is to be hoped that improvements will emerge from the work of the newly created Commission for Social Care Inspection. ${ }^{174}$ The raising of awareness of human rights amongst those living and working in such institutions should also be a priority for the Commission for Equality and Human Rights (which is likely to be established shortly and charged with a duty to promote awareness of human rights). ${ }^{175}$

Outside the institutional context, the UK disability cases are currently inconclusive. Though Article 3 has received painstaking analysis in the context of asylum seekers, its treatment in the disability context has been somewhat peremptory. There is, it is suggested, much scope for the development of Article 3 jurisprudence and protection in this area. It is sometimes said, with good reason, that disabled people have traditionally been "invisible" to human rights law; ${ }^{176}$ an invisibility which, as some commentators have speculated, may arise from a belief that disabled people are not yet "ripe for freedom" 177 or from a tendency to view them as somehow "other" and therefore not truly human. ${ }^{178}$ Although cases such as Price demonstrate a welcome recognition of their existence, their presence on the human rights stage is still little more than shadowy. If society is to demonstrate true commitment to the dignity and value of disabled people, it must allow Article 3 to play a role outside the prison gates and to reach into the unimaginable and unnecessary suffering and degradation experienced by people such as Mrs Bernard. Until this happens, aspirations to meaningful inclusion and participation will remain little more than unrealisable dreams for many disabled people.

173 See further, L. Clements and J. Read “The Dog that Didn't Bark: The Issue of Access to Rights under the European Convention on Human Rights by Disabled People" (n.97 above).

174 Set up in April 2004 by Part 2 of the Health and Social Care (Community Health and Standards) Act 2003 and charged with the inspection and regulation of social care provision.

175 Equality Bill 2005 (introduced into the House of Lords on 18 May 2005). See also DTI, Fairness for All: A New Commission for Equality and Human Rights (London: Stationary Office, 12 May 2004); and DTI, Government Response to the Consultation on Fairness for All: A New Commission for Equality and Human Rights (London: Stationary Office, 18 November 2004).

176 See, e.g. G. Quinn and T. Degener (eds.), Human Rights and Disability - the current use and future potential of United Nations human rights instruments in the context of disability (n.3 above); and A. Hendriks, "Disabled Persons and Their Right to Equal Treatment" in J.M. Mann, S. Gruskin, M.A. Grodin and G.J. Annas (eds.), Health and Human Rights (London: Routledge, 1999).

177 L. Clements and J. Read, "The Dog that Didn't Bark: The Issue of Access to Rights under the European Convention on Human Rights by Disabled People" (n.97 above), 25.

178 ibid., at 25-26. See also, A. Lawson, "The Human Rights Act 1998 and Disabled People: A Right to be Human?" in C. Harvey, (ed.), Human Rights in the Community (Oxford: Hart Publishing, 2005). 
In summary, then, disabled people continue to experience difficulties in accessing the protection of Article 3. For those living in institutional care, these difficulties are largely practical in nature; difficulties which make it extremely unlikely that Article 3 abuses will be tackled through the courts. It is therefore important that relevant authorities work to prevent the occurrence of abuse and suffering in these institutions as is required, indeed, by the positive obligations of Article 3. For those living in their own homes, the difficulties are more jurisprudential in nature. The courts have, to date, failed to develop and apply the principles of Article 3 to the suffering of disabled people in the non-institutional context. Finally, it must not be forgotten that over the entire subject there still hovers the dark cloud of an interpretation of Article 3 which would deny its protection to the most vulnerable of disabled people; an interpretation which has been ably challenged by Munby J but which has not yet been unequivocally dispelled. It is fitting to conclude with the words of Baroness Hale which, though referring to the ECHR as a whole, are particularly relevant to Article 3:

"We need to be able to use it to promote respect for the inherent dignity of all human beings but especially those who are most vulnerable to having that dignity ignored."179

179 "What Can the Human Rights Act do for my Mental Health?", Paul Sieghart Memorial Lecture London: British Institute of Human Rights, July 2004. 